\title{
Archaeological Starch
}

\author{
Les Copeland ${ }^{1, *}$ and Karen Hardy ${ }^{2,3}$ \\ 1 The University of Sydney, Sydney Institute of Agriculture, School of Life and Environmental Sciences, \\ Faculty of Science, Sydney, NSW 2006, Australia \\ 2 Catalan Institution for Research and Advanced Studies (ICREA), 08010 Barcelona, Spain; \\ karhardy2@gmail.com \\ 3 Departament de Prehistòria, Facultat de Filosofia i Lletres, Universitat Autònoma de Barcelona, \\ 08193 Barcelona, Spain \\ * Correspondence: les.copeland@sydney.edu.au; Tel.: +61-2-8627-1017
}

Received: 11 December 2017; Accepted: 31 December 2017; Published: 4 January 2018

\begin{abstract}
This article reviews evidence of how starch granules associated with archaeological artefacts provide an insight into the use of plants by our ancestors for food, medicines and cultural activities. The properties of starch relevant to archaeological contexts, methods for examining ancient starch and the types of environmental conditions that would promote survival of starch granules over hundreds of thousands of years as part of the archaeological record, are considered. Starch granules identified in dental calculus are clear indicators of the individual having consumed starchy food as part of the diet. However, surviving starch granules may be only a tiny fraction of those consumed over a lifetime and not necessarily representative of foods that were in the diet. A hypothesis, based on a combination of archaeological, physiological and genetic evidence, that plant foods containing high quantities of digestible starch were essential for the evolution of the modern human phenotype, is discussed.
\end{abstract}

Keywords: starch; archaeology; human evolution; dental calculus

\section{Introduction}

The importance of starch to modern humans, in foods and industrial products and for nutrition, is well known. Perhaps less well known is how important starch was in the evolution of modern humans from their ancient hominin ancestors. The presence of starch granules adhering to prehistoric stone tools was first highlighted about 40 years ago [1]. Since then identification of starch granules has been used increasingly in archaeological research to explore diet and cultural practices of early humans. This article will consider how starch granules associated with archaeological artefacts and in dental calculus can provide an insight into plant usage by our ancestors. We consider how starch granules could survive for hundreds of thousands of years as part of the archaeological record and review a hypothesis, based on a combination of archaeological, physiological and genetic evidence, that plant foods containing high quantities of digestible starch were essential for the evolution of the modern human phenotype [2].

\section{Properties of Starch Relevant to Archaeology}

The morphological features and physical, chemical and functional properties of starch granules are described in detail in numerous review articles (for example, [3-6]) including in this issue [7]. Nevertheless, it will be helpful to review briefly some aspects of the properties of starch relevant to archaeological contexts.

Starch granules are made up of two types of polymers of D-glucose: amylose, an essentially linear molecule and the much larger, highly branched amylopectin. These two polymers are arranged 
into alternating crystalline and amorphous layers that make up starch granules, but how these macromolecules are organized is still not fully understood. The crystalline regions contain mostly glucosyl units from amylopectin chains that form helices and are organized into crystalline clusters. The concentric arrangement of these crystalline clusters is responsible for the characteristic birefringent "Maltese Cross" pattern observed under light microscopy. Intact, native starch granules in a dry state are very stable but under the right conditions the crystalline structures can be disrupted so that the bonds between the glucose units are rendered more susceptible to attack by enzymes or dilute acids. Hence, starch can be mobilized readily in metabolic processes in living cells to release the stored glucose, which is part of its biological role.

Starch granules vary considerably between and within species with respect to size (1-100 microns in diameter), shape (spherical, elongated, lenticular, multi-lobed, compound), fine structure of amylose and amylopectin molecules, degree of crystallinity and structural inhomogeneity [3-6]). The natural variability of native starch morphology is due to the diversity in the multiple genes that encode the enzymes of the biosynthetic pathway, as reviewed elsewhere in this special issue [8]. The expression of these genes during plant growth is affected by variable interactions between plant developmental and environmental control signals $[9,10]$. Differences in morphology have been used by archaeologists to assign a botanical source to starch granules. However, as discussed subsequently this approach has limitations.

The moisture content of native granules usually ranges from $10-12 \%$ for cereal grain starches and $14-18 \%$ for root and tuber starches. The distribution of water in granules is not uniform. The crystalline structures are plasticised by water, becoming mobile at about $8 \%$ moisture.

When starch granules are heated in the presence of water they lose their molecular organisation in a process known as gelatinization [11,12]. In this process, granules absorb water and swell, amylopectin crystallites melt and amylose molecules leach out, leading to the collapse of the granules. As a result, the starch is no longer recognisable from its morphological features. The rate and extent of gelatinization depend on many factors-type of starch, moisture availability, temperature, rate and duration of heating, shear forces and other components in the mixture [12]. The "gelatinization" temperature is usually considered to represent the melting of the crystallites, as seen by the loss of birefringence. Due to the polydispersity of starch granules, the melting is not a sharp transition but occurs over a temperature range of $5-8{ }^{\circ} \mathrm{C}$ between 60 and $80^{\circ} \mathrm{C}$. Disruption of the structural order and loss of granular morphology and the accompanying changes in starch properties, occur gradually depending on the conditions of heating. At $60-80^{\circ} \mathrm{C}$, most starch granules will have lost their characteristic native morphology and will no longer be identifiable, nevertheless some remnant crystallites will remain. Complete disruption of starch granules normally requires temperatures up to $120^{\circ} \mathrm{C}$. Despite a vast amount of literature on the subject [12], there is still no clear definition of what gelatinized starch is, as it is not a precisely defined chemical entity.

On cooling, starch molecules retrograde into a new semi-ordered aggregated state, which lacks the characteristic morphological features of native granules $[13,14]$. Retrograded starch contains remnant amylopectin crystallite clusters entrapped in matrix formed by leached amylose molecules. Retrogradation takes place in minutes to hours for amylose and hours to days for amylopectin and is influenced by the rate of cooling, how well the polymer chains interact and the presence of interfering molecules $[13,14]$.

Raw (i.e., uncooked) starch is hydrolysed slowly by amylases present in saliva or the gut, with the rate and extent of hydrolysis influenced by varietal differences and amylose content. In contrast, cooked starch is hydrolysed rapidly, regardless of the source [12,15-17]. Even moderate cooking that causes no visible disruption to granules can greatly increase the susceptibility of starch to hydrolysis by amylases [18]. 


\section{Starch as an Archaeological Tool}

There is little doubt that starch granules survive over archaeological time, as the images in Figure 1 show. Hence, morphological analysis of starch granules retrieved from dental calculus and ancient tools and pots is used widely in bioarchaeological studies. Many studies involving starch have provided evidence of plant use in archaeological contexts, for example: agricultural beginnings and plant domestication [19-38]; hominin and pre-agricultural human diet and ancient technologies [39-53]; prehistoric chimpanzee food processing and diet [54]; environmental reconstruction [55]. Table 1 shows the archaeological time periods referred to in this article.
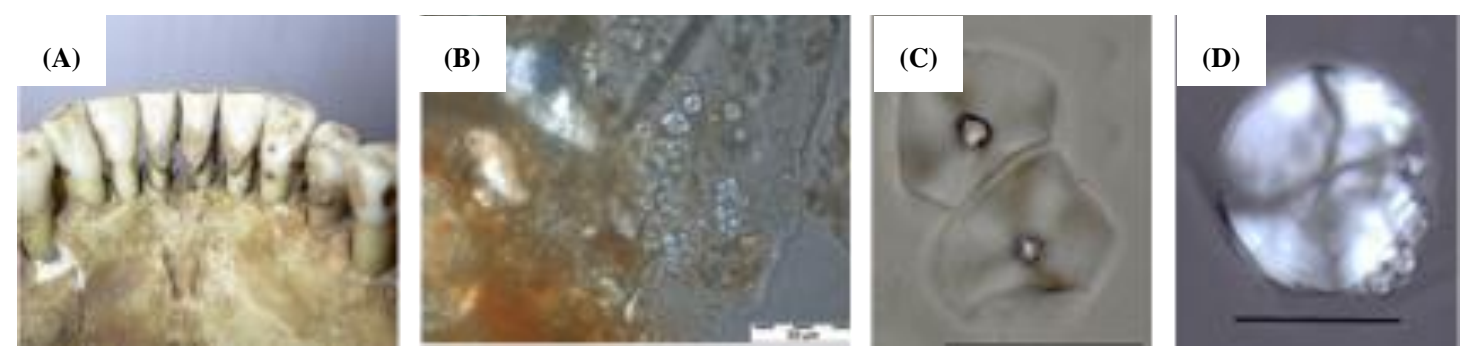

Figure 1. Dental calculus as a source of archaeological starch (A) Human mandible from Tarbat Medieval site, Portmahomack, Scotland showing subgingival dental calculus (from [42], with permission). (B) Group of starch granules embedded in Neanderthal dental calculus matrix from El Sidrón cave, Spain, dating to 50,000 ya (from [43], with permission). (C) Starch granules extracted from dental calculus from Qesem Cave, Israel, dating between 420,000-200,000 years ago (from [45], with permission). (D) Starch granule extracted from dental calculus from Sima del Elefante, Spain, dating to 1.2 Mya (bar = 200 microns; from [46], with permission).

Table 1. Archaeological time periods.

\begin{tabular}{lcc}
\hline \multicolumn{1}{c}{ Geological Epochs } & Years before Present & \\
\hline Pleistocene & & \\
Early & 2.6 million-781,000 & \\
Middle & $781,000-126,000$ & \\
Late & $126,000-11,500$ & Examples \\
Holocene & $11,500-$ present & \\
\hline \multicolumn{1}{c}{ Cultural Periods } & Years before Present & \\
\hline Palaeolithic & & Qesem Cave [45], Sima del Elefante [46] \\
Lower & 3.3 million- 300,000 & El Sidrón [43], Shanidar [41], Spy [41] \\
Middle & $\sim 300,000-\sim 45,000$ & Various sites, e.g., [50,51] \\
Upper & $\sim 45,000-\sim 11,500$ & Various sites e.g., [42,56] \\
Mesolithic & $\sim 11,500-$ variable $(\sim 8000-\sim 2000)$ & \\
\hline
\end{tabular}

\section{Analysis of Archaeological Starch}

The simplest method for identifying starch granules is under a light microscope with brightfield, phase contrast or polarised illumination, which reveals the characteristic birefringent "Maltese Cross" pattern. Starch granules are identified from their size, morphological features and birefringent pattern. Preparation of samples for microscopy usually involves removal of soil and mineralised material using acids, which can cause changes to starch granules. As birefringence is a property of semi-crystalline materials and is not unique to starch [57], susceptibility to breakdown by the specific enzyme alpha-amylase can be used to confirm the presence of starch and demonstrate its biochemical functionality [42]. The effect of alpha-amylase on starch isolated from dental calculus is shown in Figure 2. 

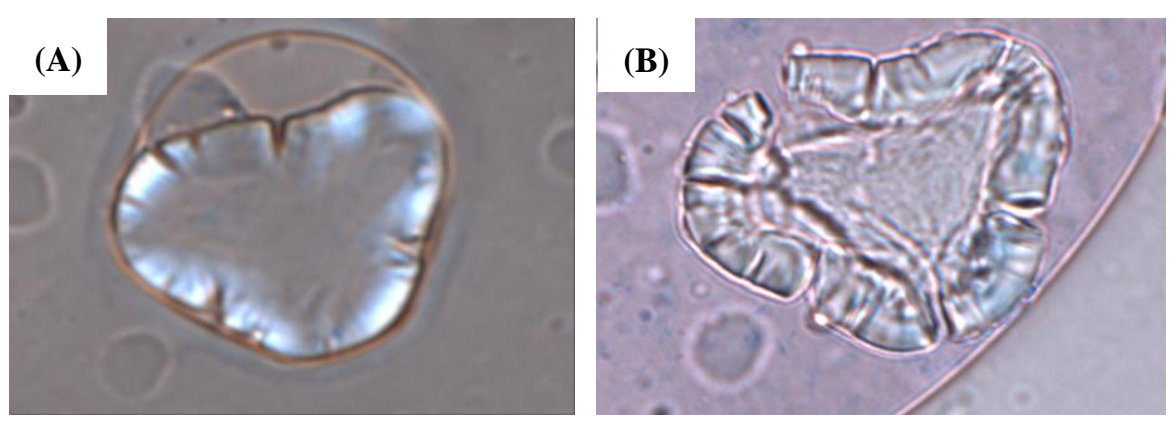

Figure 2. Starch granules from dental calculus before (A) and after $18 \mathrm{~h}$ exposure (B) to alpha amylase [58].

Plant identification usually involves the visual comparison of individual archaeological granules with modern reference material using a method that was pioneered over 100 years ago [59]. However, this approach has major limitations. For one, starch from modern, domesticated plants and that from their ancient wild ancestors may not be directly comparable morphologically; reference collections relevant to starches from ancestral plant varieties are not available. Moreover, inspection of scanning electron microscope images of starch granules from multiple plant sources reveals considerable similarities in morphology between and within species [60]. A less subjective, morphometric approach proposed by Torrence et al. [61] uses measurements obtained interactively from images of starch granules and multivariate analysis for classification (e.g., [62,63]). However, a study using automated image analysis and classification with modern starch granules revealed that, while some plant genera do produce morphologically characteristic starch granules, there was significant overlap between many species [64]. Just as for visual morphological comparisons, morphometric methods require the availability of a suitable database of reference images. Nevertheless, in certain cases, it may be possible to identify a general plant source. For example, seeds of wheat, barley and rye have a distinctive bimodal distribution and it was possible to infer an origin from a related ancestral grass species when both large and small granules were seen together in the same sample [46]. In general, while the presence of starch granules in archaeological materials can indicate consumption of starchy foods, identification of plant origin is problematic.

Scanning electron microscopy (SEM; resolution down to $0.5 \mathrm{~nm}$ ) is also used in archaeological research, whereas atomic force microscopy (examines surface properties at a resolution down to $0.3 \mathrm{~nm}$ in the $\mathrm{x}, \mathrm{y}$ dimensions and $0.01 \mathrm{~nm}$ in the $\mathrm{z}$ dimension), confocal laser scanning microscopy (for 3-D images and optical slices) and micro X-ray computed tomography (for surface and internal imaging at micron resolution) are tools that could be useful but are not yet widely used to examine archaeological starch. Spectroscopic and scattering techniques (for example NMR to measure helical content; Fourier transform infra-red and Raman spectroscopy to determine structural order; small angle X-ray or neutron scattering and X-ray diffraction for crystallinity, arrangement of crystalline and amorphous domains inside granules) are used extensively in starch research. However, these methods, as well as chemical analyses of the molecular properties of starch, are unsuitable for the small numbers of granules usually present in archaeological samples.

\section{Starch from Archaeological Materials}

\subsection{Residues from Grinding Stones and Pots}

Starch granules identified in residual material adhering to the surfaces of ancient grinding stones have been used to infer early plant processing. Examples of studies include: the recovery of starch granules suggested to be from Typha spp. from around 30,000 years ago, during the Upper Palaeolithic and long before the arrival of farming [51]; root crop horticulture in Panama [21,33]; use of cereal grains [50,65]; seed grinding [66]; use of wild plants [44,65,67]; the use of stone tools [68]. This approach 
has also become popular in recent years in China [29,69-75]). Likewise, starch granules extracted from residues inside ancient pots used for cooking have been suggested to originate from starchy foods $[36,76,77]$. However, some concerns have been raised regarding the integrity of the evidence based on such findings of starch granules and their use to infer plant species of origin [78-80].

\subsection{Dental Calculus}

Starch has been shown to survive well in dental calculus, which forms mainly in the sub gingival crevice. The presence of starch in dental calculus is less contentious because in its micro-calcified environment it is protected from amylases. Moreover, microbial communities there are proteolytic rather than saccharolytic, which also aids the survival of starch.

Starch has been found in samples of dental calculus ranging from Lower Palaeolithic hominins to Victorians [41-47], including from sources as diverse as Norse Shetland (Scotland), pre-Mesolithic Sudan [44], from chimpanzees [56] early Balkan agricultural populations [81] and from tropical environments [53,82]. Recovery of data on the use of plants, particularly for the early stages of the Palaeolithic, is very limited [83]. Therefore, starch granules and other material recovered from dental calculus from the Palaeolithic in particular, are an important source of information that would otherwise be missing from the archaeological record.

Items found in dental calculus represent an unknown but tiny, random amount of material that entered the mouth in one of various ways, including ingestion in food, as medication, residues from cultural activities or through breathing [84]. In the case of starchy food, each item eaten will contain billions of starch granules. This can be seen from a simple calculation based on an assumption that the volume of an "average" starch granule (say, an ellipsoid with dimensions of $20 \times 10 \times 10 \mu \mathrm{m}$ ) is roughly $10^{-7}$ nanolitres. If we further assume the density of starch is $1.5 \mathrm{~g} /$ millilitres (i.e., $1.5 \mu \mathrm{g} /$ nanolitre), the weight of such an "average" starch granule is about $1.5 \times 10^{-7} \mu \mathrm{g}$, which means that the number of granules in a cereal grain containing approximately $20 \mathrm{mg}$ of starch will be over one billion; the number of starch granules in a small starchy tuberous root would be substantially greater. Hence, the numbers of starch granules ingested in a lifetime will be immense, while the minute numbers of granules recovered from dental calculus samples will represent an infinitesimally small, random sample of items of food eaten at some point during an individual's life.

The presence of starch granules in dental calculus is normally indicative of deliberate food ingestion. However, such starch granules would not be representative of diet [56,85]. Moreover, starch granules in dental calculus only represent raw or ineffectively cooked food, as cooked granules almost certainly will not be recognisable or survive once exposed to salivary amylase. Disrupted starch granules observed in dental calculus can result from diagenesis [86] or from mechanical damage. Given the vast quantities of starch granules ingested during life, the minimal numbers recovered from dental calculus and the lack of understanding of the way dental calculus builds up, dietary interpretation based on this line of evidence is problematic. However, direct evidence for the use of plants is extremely rare in the Palaeolithic and the presence of starch granules in dental calculus has provided the first direct evidence for plant consumption during this very long period.

\section{Starch and the Evolution of the Modern Human Phenotype}

Modern humans require a reliable source of glycaemic carbohydrate to support the normal functioning of brain, kidney, red blood cells and reproductive tissues. The brain accounts for $20-25 \%$ of adult basal metabolic energy expenditure [87] and red blood cells additionally require approximately $20 \mathrm{~g}$ glucose per day [88]. This glucose requirement is normally met from dietary carbohydrates and gluconeogenesis from non-carbohydrate sources (e.g., the glycerol moiety of triglycerides, some amino acids), or absorption of short chain fatty acids such as propionate produced in fermentations by gut microflora in the colon [89]. Glucose is the main energy source for foetal growth and low glucose availability can compromise foetal survival $[90,91]$. 
According to a hypothesis proposed by Hardy et al. [2], the regular consumption of starchy plant foods offers a coherent explanation for the provision of energy to the evolving brain during the late Pliocene and Early Pleistocene. The development of cooking and concomitant increases in salivary amylase expression, could explain how the rapid increases in brain size from the Middle Pleistocene onward were energetically affordable. Several key features in human evolution are considered directly linked to alterations in dietary composition [2]. These include: changes in tooth morphology [92]; a reduction in the size of the digestive tract, achieved by 1.8 million years ago [93]; an accelerated increase in brain size from around 800,000 years ago [94]; increased aerobic capacity by around 2 million years ago [95].

The increased availability of glucose from cooked starchy foods would have been advantageous for these evolutionary changes. Cooked starch would have provided an increased energy source for human tissues with high glucose demands, such as the brain, red blood cells and the developing foetus. Salivary amylases are largely ineffective on raw starch but cooking substantially increases their energy-yielding potential [17]. Copy number variation in the salivary amylase genes would have become advantageous and may have further enhanced the role of starch in human evolution when cooking became widespread among early hominins [2].

There is secure evidence for the controlled use of fire, which would have been essential for cooking, from around 400,000 years ago [96,97], although some evidence indicates fire may have been used over $1 \mathrm{~m}$ years ago [98]. Humans are the only species that cook food, which is considered to have been a transformational event in human evolution [99,100]. Hardy et al. [2] argue that the increase in oral starch digestion rates due to evolution of copy number variation in the $A M Y 1$ gene overlap the time frame for hominin adoption of fire for cooking.

\section{Challenges in the Use of Starch in Archaeology}

As starch granules are made up of organic molecules, the question of how they can survive for hundreds of thousands of years and retain their crystallinity and susceptibility to amylolytic attack is of considerable interest to archaeologists [101]. While the answer is not really known, we can hypothesize on the type of conditions that would promote survival of starch granules.

The micro-environment around deposition of granules is important [79]. Conditions likely to promote survival would be a low moisture environment, or more precisely an environment with low water-availability (i.e., low water activity), a pH close to neutral and relatively low ambient temperature. At temperatures below the onset of gelatinization, native granules can reversibly absorb up to about $30 \%$ of their weight of water without losing their crystallinity and birefringence [102]. The extent to which the original native structure is maintained on water loss/absorption is not known but might be relevant to the morphological stability of archaeological starch during long-term deposition. Low water availability would limit water penetration into and movement within the granules, thereby minimising hydrogen bond disruption and preserving structural integrity. Moreover, at a low water activity, amylases released into the soil matrix by microbes would have reduced mobility and enzyme activity and hence limited ability to attack starch granules. The presence in the matrix of other materials that can sequester moisture would contribute to the conditions of low water activity.

Although seemingly intact and functional starch granules are abundant in archaeological specimens, there is no indication of the extent to which they have undergone morphological changes. The equilibration of moisture content between granules and their environment over many thousands of years, even at low temperatures, could cause changes to their internal organization with consequent effects on morphology [86]. Nor is there any indication of the proportion of the original population of granules that have survived. It is likely that out of an original population of billions of granules, only a few survived in a condition to be identified as starch granules. These may have been in an environment conducive to survival and/or may have had an inherently more stable crystalline structure. 
The possibilities of the effects of long-term storage on starch granule morphology, poses challenges for the use of starch to identify ancient plants. Likewise, effects of evolutionary changes over time in plant species may have brought about in differences in the shape or size of starch granules. Modern domesticated varieties of our food plants are very different from their ancient wild ancestors as a result of thousands of years of selective plant breeding. All of these suggest that specific plant identification based on current starch morphological methods needs to be approached with caution. Finally, starch is ubiquitous in today's world; it is present in all plants, in most foods and is common in a laboratory environment. Hence, it is essential to establish the authenticity of archaeological starch and to differentiate it from contaminating starch [78].

\section{Conclusions}

The study of ancient starch granules has the potential to provide information on ancient plant use, in certain cases, where no other evidence for plant use survives but the limitations of what can be achieved need to be understood. We need a better understanding of the extent to which surviving granules represent the original population, of how starch survives and remains biochemically active in some archaeological contexts and what the effects of natural ageing are on starch granule morphology. Starch granules identified in dental calculus are clear indicators of an individual having consumed starchy food as part of the diet. However, these surviving starch granules may be only a tiny fraction of those consumed over a lifetime and not necessarily representative of the foods that were in the diet. The contribution of digestible carbohydrates to the evolution of the modern human phenotype is a matter of interest to present-day concerns about dietary starch.

Acknowledgments: The authors acknowledge the late Tony Blakeney for his contributions to discussions and for his help with the images in Figure 2.

Author Contributions: Les Copeland and Karen Hardy prepared the manuscript. Both authors read and approved the submitted version.

Conflicts of Interest: The authors declare no conflict of interest.

\section{References}

1. Bruier, F.L. New Clues to stone tool function: Plant and animal residues. Am. Antiq. 1976, 41, 478-484. [CrossRef]

2. Hardy, K.; Brand Miller, J.; Brown, K.J.; Thomas, M.G.; Copeland, L. The importance of dietary carbohydrate in human evolution. Q. Rev. Biol. 2015, 90, 251-268. [CrossRef] [PubMed]

3. Copeland, L.; Blazek, J.; Salman, H.; Tang, C.M. Form and functionality of starch. Food Hydrocoll. 2009, 23, 1527-1534. [CrossRef]

4. Delcour, J.A.; Hoseney, R.C. Principles of Cereal Science and Technology, 3rd ed.; AACC-International: St Paul, MN, USA, 2010; Chapter 2, pp. 23-51, ISBN 978-1-891127-63-2.

5. Perez, S.; Bertoft, E. The molecular structures of starch components and their contribution to the architecture of starch granules: A comprehensive review. Starch/Stärke 2010, 62, 389-420. [CrossRef]

6. Eliasson, A.-C.; Bergenståhl, B.; Nilsson, L.; Sjöö, M. From molecules to products: Some aspects of structure-function relationships in cereal starches. Cereal Chem. 2013, 90, 326-334. [CrossRef]

7. Bertoft, E. Understanding starch structure: Recent progress. Agronomy 2017, 7, 56. [CrossRef]

8. Tetlow, I.J.; Emes, M.J. Starch Biosynthesis in the Developing Endosperms of Grasses and Cereals. Agronomy 2017, 7, 81. [CrossRef]

9. Geigenberger, P. Regulation of Starch Biosynthesis in Response to a Fluctuating Environment. Plant Physiol. 2011, 155, 1566-1577. [CrossRef] [PubMed]

10. Beckles, D.B.; Thitisaksakul, M. How environmental stress affects starch composition and functionality in cereal endosperm. Starch/Stärke 2014, 66, 58-71. [CrossRef]

11. Hoover, R. The impact of heat-moisture treatment on molecular structures and properties of starches isolated from different botanical sources. Crit. Rev. Food Sci. Nutr. 2010, 50, 835-847. [CrossRef] [PubMed] 
12. Wang, S.; Copeland, L. Molecular disassembly of starch granules during gelatinization and its effect on starch digestibility: A review. Food Funct. 2013, 4, 1564-1580. [CrossRef] [PubMed]

13. Wang, S.; Li, C.; Copeland, L.; Niu, Q.; Wang, S. Starch Retrogradation: A Comprehensive Review. Comp. Rev. Food Sci. Food Saf. 2015, 14, 568-585. [CrossRef]

14. Goesaert, H.; Brijs, K.; Veraverbeke, W.S.; Courtin, C.M.; Gebruers, K.; Delcour, J.A. Wheat flour constituents: How they impact bread quality and how to impact their functionality. Trends Food Sci. Technol. 2005, 16, 12-30. [CrossRef]

15. Cummings, J.H.; Englyst, H.N. Gastrointestinal effects of food carbohydrate. Am. J. Clin. Nutr. 1995, 61, 938S-945S. [PubMed]

16. Tester, R.F.; Qi, X.; Karkalas, J. Hydrolysis of native starches with amylases. Anim. Feed Sci. Technol. 2006, 130, 39-54. [CrossRef]

17. Butterworth, P.J.; Warren, F.J.; Ellis, P.R. Human $\alpha$-amylase and starch digestion: An interesting marriage. Starch/Stärke 2011, 63, 395-405. [CrossRef]

18. Wang, S.; Wang, S.; Liu, L.; Wang, S.; Copeland, L. Structural Orders of Wheat Starch Do Not Determine the In Vitro Enzymatic Digestibility. J. Agric. Food Chem. 2017, 65, 1697-1706. [CrossRef] [PubMed]

19. Balter, M. Starch Reveals Crop Identities. Science 2007, 316, 1834. [CrossRef] [PubMed]

20. Denham, T.P.; Haberle, S.G.; Lentfer, C.; Fullagar, R.; Field, J.; Therin, M.; Porch, N.; Winsborough, B. Origins of agriculture at Kuk Swamp in the Highlands of New Guinea. Science 2003, 301, 189-193. [CrossRef] [PubMed]

21. Dickau, R.; Ranere, A.J.; Cooke, R.G. Starch grain evidence for the preceramic dispersals of maize and root crops into tropical dry and humid forests of Panama. Proc. Natl. Acad. Sci. USA 2007, 104, 3651-3656. [CrossRef] [PubMed]

22. Fullagar, R.; Field, J.; Denham, T.; Lentfer, C. Early and mid-Holocene tool-use and processing of taro (Colocasia esculenta), yam (Dioscorea sp.) and other plants at Kuk Swamp in the highlands of Papua New Guinea. J. Arch. Sci. 2006, 33, 595-614. [CrossRef]

23. Horrocks, M.; Irwin, G.; Jones, M.; Sutton, D. Starch grains and xylem cells of sweet potato (Ipomoea batatas) and bracken (Pteridium esculentum) in archaeological deposits from northern New Zealand. J. Arch. Sci. 2004, 31, 251-258. [CrossRef]

24. Horrocks, M.; Nunn, P.D. Evidence for introduced taro (Colocasia esculenta) and lesser yam (Dioscorea esculenta) in Lapita-era (c. 3050-2500 cal. years BP) deposits from Bourewa, southwest Viti Levu Island, Fiji. J. Arch. Sci. 2007, 34, 739-748. [CrossRef]

25. Horrocks, M.; Grant-Mackie, J.; Matisoo-Smith, E. Introduced taro (Colocasia esculenta) and yams (Dioscorea spp.) in Podtanean (2700-1800 years BP) deposits from Mé Auré Cave (WMD007), Moindou, New Caledonia. J. Arch. Sci. 2008, 35, 169-180. [CrossRef]

26. Iriarte, J.; Holst, I.; Marozzi, O.; Listopad, C.; Alonso, E.; Rinderknecht, A.; Montana, J. Evidence for cultivar adoption and emerging complexity during the mid-Holocene in the La Plata basin. Nature 2004, 432, 614-617. [CrossRef] [PubMed]

27. Liu, L.; Field, J.; Fullagar, R.; Bestel, S.; Chen, X.; Ma, X. What did grinding stones grind? New light on Early Neolithic subsistence economy in the Middle Yellow River Valley, China. Antiquity 2010, 84, 816-833. [CrossRef]

28. Loy, T.H.; Spriggs, M.; Wickler, S. Direct evidence for human use of plants 28,000 years ago: Starch residues on stone artefacts from the northern Solomon Islands. Antiquity 1992, 66, 898-912. [CrossRef]

29. Lu, H.; Yang, X.; Ye, M.; Liu, K.-B.; Xia, Z.; Ren, X.; Cai, L.; Wu, N.; Liu, T.-S. Millet noodles in Late Neolithic China. Nature 2005, 437, 967-968. [CrossRef] [PubMed]

30. Neumann, K. New Guinea: A cradle of agriculture. Science 2003, 301, 180-181. [CrossRef] [PubMed]

31. Pearsall, D.M.; Chandler-Ezell, K.; Zeidler, J.A. Maize in ancient Ecuador: Results of residue analysis of stone tools from the Real Alto site. J. Arch. Sci. 2004, 31, 423-442. [CrossRef]

32. Perry, L.; Dickau, R.; Zarrillo, S.; Holst, I.; Pearsall, D.M.; Piperno, D.R.; Berman, M.J.; Cooke, R.G.; Rademaker, K.; Ranere, A.J.; et al. Starch fossils and the domestication and dispersal of chilli peppers (Capsicum spp. L.) in the Americas. Science 2007, 315, 986-988. [CrossRef] [PubMed]

33. Piperno, D.R.; Holst, I. The presence of starch grains on prehistoric stone tools from the humid neotropics: Indications of early tuber use and agriculture in Panama. J. Arch. Sci. 1998, 25, 765-776. [CrossRef] 
34. Piperno, D.R.; Ranere, A.J.; Holst, I.; Iriarte, J.; Dickau, R. Starch grain and phytolith evidence for early ninth millennium B.P. maize from the Central Balsas River Valley, Mexico. Proc. Natl. Acad. Sci. USA 2009, 106, 5019-5024. [CrossRef] [PubMed]

35. Ranere, A.J.; Piperno, D.R.; Holst, I.; Dickau, R.; Iriarte, J. The cultural and chronological context of early Holocene maize and squash domestication in the Central Balsas River Valley, Mexico. Proc. Natl. Acad. Sci. USA 2009, 106, 5014-5018. [CrossRef] [PubMed]

36. Zarrillo, S.; Pearsall, D.M.; Raymond, J.S.; Tisdale, M.A.; Quon, D.J. Directly dated starch residues document early formative maize (Zea mays L.) in tropical Ecuador. Proc. Natl. Acad. Sci. USA 2008, 105, 5006-5011. [CrossRef] [PubMed]

37. Duncan, N.; Pearsall, D.M.; Benfer, R.A., Jr. Gourd and squash artifacts yield starch grains of feasting foods from preceramic Peru. Proc. Natl. Acad. Sci. USA 2009, 106, 13202-13206. [CrossRef] [PubMed]

38. Piperno, D.R.; Dillehay, T.D. Starch grains on human teeth reveal early broad crop diet in northern Peru. Proc. Natl. Acad. Sci. USA 2008, 105, 19622-19627. [CrossRef] [PubMed]

39. Barker, G.; Barton, H.; Bird, M.; Daly, P.; Datan, I.; Dykes, A.; Farr, L.; Gilbertson, D.; Harrisson, B.; Hunt, C.; et al. The 'human revolution' in lowland tropical Southeast Asia: The antiquity and behavior of anatomically modern humans at Niah Cave (Sarawak, Borneo). J. Hum. Evol. 2007, 52, 243-261. [CrossRef] [PubMed]

40. Fullagar, R.; Field, J. Pleistocene seed-grinding implements from the Australian arid zone. Antiquity 1997, 71, 301-310. [CrossRef]

41. Henry, A.; Brooks, A.; Piperno, D.R. Microfossils in calculus demonstrate consumption of plants and cooked foods in Neanderthal diets (Shanidar III, Iraq; Spy I and II, Belgium). Proc. Natl. Acad. Sci. USA 2011, 108, 486-491. [CrossRef] [PubMed]

42. Hardy, K.; Blakeney, T.; Copeland, L.; Kirkham, J.; Wrangham, R.; Collins, M. Starch granules, dental calculus and new perspectives on ancient diet. J. Arch. Sci. 2009, 36, 248-255. [CrossRef]

43. Hardy, K.; Buckley, S.; Collins, M.J.; Estalrrich, A.; Brothwell, D.; Copeland, L.; García-Tabernero, A.; García-Vargas, S.; de la Rasilla, M.; Lalueza-Fox, C.; et al. Neanderthal medics? Evidence for food, cooking and medicinal plants entrapped in dental calculus. Naturwissenschaften 2012, 99, 617-626. [CrossRef] [PubMed]

44. Buckley, S.; Usai, D.; Jakob, T.; Radini, A.; Hardy, K. Dental calculus reveals unique insights into food items, cooking and plant processing in prehistoric central Sudan. PLoS ONE 2014, 9, e100808. [CrossRef] [PubMed]

45. Hardy, K.; Radini, A.; Buckley, S.; Sarig, R.; Copeland, L.; Gopher, A.; Barkai, R. Dental calculus reveals potential respiratory irritants and ingestion of essential plant-based nutrients at Lower Palaeolithic Qesem Cave Israel. Quat. Int. 2016, 398, 129-135. [CrossRef]

46. Hardy, K.; Radini, A.; Buckley, S.; Blasco, R.; Copeland, L.; Burjachs, F.; Girbal, J.; Yll, R.; Carbonell, E.; Bermúdez de Castro, J.M. Diet and environment 1.2 million years ago revealed through analysis of dental calculus from Europe's oldest hominin at Sima del Elefante, Spain. Sci. Nat. 2017, 104, 2. [CrossRef] [PubMed]

47. Weyrich, L.S.; Duchene, S.; Soubrier, J.; Arriola, L.; Llamas, B.; Breen, J.; Morris, A.G.; Alt, K.W.; Caramelli, D.; Dresely, V.; et al. Neanderthal behaviour, diet and disease inferred from ancient DNA in dental calculus. Nature 2017, 544, 357-361. [CrossRef] [PubMed]

48. Lombard, M. Evidence of hunting and hafting during the Middle Stone Age at Sibidu Cave, KwaZulu-Natal, South Africa: A multianalytical approach. J. Hum. Evol. 2005, 48, 279-300. [CrossRef] [PubMed]

49. Mercader, J. Mozambican grass seed consumption during the Middle Stone Age. Science 2009, 326, $1680-1683$. [CrossRef] [PubMed]

50. Piperno, D.R.; Weiss, E.; Holst, I.; Nadel, D. Processing of wild cereal grains in the Upper Palaeolithic revealed by starch grain analysis. Nature 2004, 430, 670-673. [CrossRef] [PubMed]

51. Revedin, A.; Aranguren, B.; Becattini, R.; Longo, L.; Marconi, E.; Mariotti Lippi, M.; Skakun, N.; Sinitsyn, A.; Spiridonova, E.; Svoboda, J. Thirty thousand-year-old evidence of plant food processing. Proc. Natl. Acad. Sci. USA 2010, 107, 18815-18819. [CrossRef] [PubMed]

52. Summerhayes, G.; Leavesley, M.; Fairbairn, A.; Mandui, H.; Field, J.; Ford, A.; Fullagar, R. Human Adaptation and Plant Use in Highland New Guinea 49,000 to 44,000 Years Ago. Science 2010, 330, 78-81. [CrossRef] [PubMed]

53. Wesolowski, V.; Ferraz Mendonça de Souza, S.M.; Reinhard, K.J.; Ceccantini, G. Evaluating microfossil content of dental calculus from Brazilian sambaquis. J. Arch. Sci. 2010, 37, 1326-1338. [CrossRef] 
54. Mercader, J.; Barton, H.; Gillespie, J.; Harris, J.; Kuhn, S.; Tyler, R.; Boesch, C. 4300-Year-old chimpanzee sites and the origins of percussive stone technology. Proc. Natl. Acad. Sci. USA 2007, 104, 3043-3048. [CrossRef] [PubMed]

55. Lentfer, C.; Therin, M.; Torrence, R. Starch grains and environmental reconstruction: a modern test case from West New Britain, Papua New Guinea. J. Arch. Sci. 2002, 29, 687-698. [CrossRef]

56. Power, R.C.; Salazar-García, D.C.; Wittig, R.M.; Freiberg, M.; Henry, A.G. Dental calculus evidence of Taï Forest Chimpanzee plant consumption and life history transitions. Sci. Rep. 2015, 5, 15161. [CrossRef] [PubMed]

57. Haslam, M. Potential misidentification of in situ archaeological tool-residues: Starch and conidia. J. Arch. Sci. 2006, 33, 114-121. [CrossRef]

58. Copeland, L.; Blakeney, A.B.; Hardy, K. Exposure of starch granules from dental calculus to alpha-amylase. The University of Sydney: Sydney, Australia, Unpublished data. 2017.

59. Reichert, E.T. The Differentiation and Specificity of Starches in Relation to Genera, Species, etc.: Stereochemistry Applied to Protoplasmic Processes and Products and As a Strictly Scientific Basis for the Classification of Plants and Animals; Carnegie Institution of Washington: Washington, DC, USA, 1913.

60. Jane, J.L.; Kasemasuwan, T.; Leas, S.; Zobel, H.; Robyt, J.F. Anthology of starch granule morphology by scanning electron microscopy. Starch/Stärke 1994, 46, 121-129. [CrossRef]

61. Torrence, R.; Wright, R.; Conway, R. Identification of starch granules using image analysis and multivariate techniques. J. Arch. Sci. 2004, 31, 519-532. [CrossRef]

62. Arráiz, H.; Barbarin, N.; Pasturel, M.; Beaufort, L.; Domínguez-Rodrigo, M.; Barboni, D. Starch granules identification and automatic classification based on an extended set of morphometric and optical measurements. J. Arch. Sci. Rep. 2016, 7, 169-179. [CrossRef]

63. Coster, A.C.; Field, J.H. What starch grain is that? A geometric morphometric approach to determining plant species origin. J. Arch. Sci. 2015, 58, 9-25. [CrossRef]

64. Wilson, J.; Hardy, K.; Allen, R.; Copeland, L.; Wrangham, R.; Collins, M. Automated classification of starch granules using supervised pattern recognition of morphological properties. J. Arch. Sci. 2010, 37, 594-604. [CrossRef]

65. Nadel, D.; Piperno, D.R.; Holst, I.; Snir, A.; Weiss, E. New evidence for the processing of wild cereal grains at Ohalo II, a 23,000-year-old campsite on the shore of the Sea of Galilee, Israel. Antiquity 2012, 86, 990-1003. [CrossRef]

66. Fullagar, R.; Hayes, E.; Stephenson, B.; Field, J.; Matheson, C.; Stern, N.; Fitzsimmons, K. Evidence for Pleistocene seed grinding at Lake Mungo, south-eastern Australia. Archaeol. Ocean. 2015, 50, 3-19. [CrossRef]

67. Lucarini, G.; Radini, A.; Barton, H.; Barker, G. The exploitation of wild plants in Neolithic North Africa. Use-wear and residue analysis on non-knapped stone tools from the Haua Fteah cave, Cyrenaica, Libya. Quat. Int. 2016, 410, 77-92. [CrossRef]

68. Perry, L. Starch analyses reveal the relationship between tool type and function: An example from the Orinoco valley of Venezuela. J. Arch. Sci. 2004, 31, 1069-1081. [CrossRef]

69. Yang, X.; Perry, L. Identification of ancient starch grains from the tribe Triticeae in the North China Plain. J. Arch. Sci. 2013, 40, 3170-3177. [CrossRef]

70. Yang, X.; Zhang, J.; Perry, L.; Ma, Z.; Wan, Z.; Li, M.; Diao, X.; Lu, H. From the modern to the archaeological: Starch grains from millets and their wild relatives in China. J. Arch. Sci. 2012, 39, 247-254. [CrossRef]

71. Yang, X.; Wan, Z.; Perry, L.; Lu, H.; Wang, Q.; Zhao, C.; Li, J.; Xie, F.; Yu, J.; Cui, T.; et al. Early millet use in northern China. Proc. Natl. Acad. Sci. USA 2012, 109, 3726-3730. [CrossRef] [PubMed]

72. Yang, X.; Yu, J.; Lü, H.; Cui, T.; Guo, J.; Ge, Q. Starch grain analysis reveals function of grinding stone tools at Shangzhai site, Beijing. Sci. China Ser. D Earth Sci. 2009, 52, 1164-1171. [CrossRef]

73. Liu, L.; Field, J.; Fullagar, R.; Zhao, C.; Chen, X.; Yu, J. A functional analysis of grinding stones from an early Holocene site at Donghulin, North China. J. Arch. Sci. 2010, 37, 2630-2639. [CrossRef]

74. Tao, D.; Wu, Y.; Guo, Z.; Hill, D.V.; Wang, C. Starch grain analysis for groundstone tools from Neolithic Baiyinchanghan site: Implications for their function in Northeast China. J. Arch. Sci. 2011, 38, 3577-3583. [CrossRef]

75. Walsh, R.; Lee, G.A.; Liu, L.; Chen, X. Millet grain morphometry as a tool for social inference: A case study from the Yiluo basin, China. Holocene 2016, 26, 1778-1787. [CrossRef] 
76. Crowther, A. Starch residues on undecorated Lapita pottery from Anir, New Ireland. Archaeol. Ocean. 2005, 40, 62-66. [CrossRef]

77. Yang, X.; Jiang, L. Starch grain analysis reveals ancient diet at Kuahuqiao site, Zhejiang Province. Chin. Sci. Bull. 2010, 55, 1150-1156. [CrossRef]

78. Crowther, A.; Haslam, M.; Oakden, N.; Walde, D.; Mercader, J. Documenting contamination in ancient starch laboratories. J. Arch. Sci. 2014, 49, 90-104. [CrossRef]

79. Haslam, M. The decomposition of starch grains in soils: Implications for archaeological residue analyses. J. Arch. Sci. 2004, 31, 1715-1734. [CrossRef]

80. Laurence, A.R.; Thoms, A.V.; Bryant, V.M.; McDonough, C. Airborne starch granules as a potential contamination source at archaeological sites. J. Ethnobiol. 2011, 31, 213-232. [CrossRef]

81. Cristiani, E.; Radini, A.; Edinborough, M.; Borić, D. Dental calculus reveals Mesolithic foragers in the Balkans consumed domesticated plant foods. Proc. Natl. Acad. Sci. USA 2016, 113, 10298-10303. [CrossRef] [PubMed]

82. Mickleburgh, H.L.; Pagán-Jiménez, J.R. New insights into the consumption of maize and other food plants in the pre-Columbian Caribbean from starch grains trapped in human dental calculus. J. Arch. Sci. 2012, 39, 2468-2478. [CrossRef]

83. Hardy, K.; Kubiak-Martens, L. (Eds.) Wild Harvest: Plants in the Hominin and Pre-Agrarian Human Worlds. In Studying Scientific Archaeology Series; Oxbow Books: Oxford, UK, 2016; pp. 1-17. ISBN 978-178570-123-8.

84. Radini, A.; Buckley, S.; Nikita, E.; Copeland, L.; Hardy, K. Beyond Food: The rich and varied pathways for inclusion of microscopic remains into ancient dental calculus. Am. J. Phys. Anthropol. 2017, 162, 71-83. [CrossRef] [PubMed]

85. Leonard, C.; Vashro, L.; O'Connell, J.F.; Henry, A.G. Plant microremains in dental calculus as a record of plant consumption: A test with Twe forager-horticulturalists. J. Arch. Sci. Rep. 2015, 2, 449-457. [CrossRef]

86. Collins, M.J.; Copeland, L. Ancient starch: Cooked or just old? Proc. Natl. Acad. Sci. USA 2011, 108, E145. [CrossRef] [PubMed]

87. Fonseca-Azevedo, K.; Herculano-Houzel, S. Metabolic constraint imposes trade off between body size and number of brain neurons in human evolution. Proc. Natl. Acad. Sci. USA 2012, 109, 18571-18576. [CrossRef] [PubMed]

88. Mulquiney, P.J.; Bubb, W.A.; Kuchel, P.W. Model of 2,3-bisphosphoglycerate metabolism in the human erythrocyte based on detailed enzyme kinetic equations: In vivo kinetic characterization of 2,3-bisphosphoglycerate synthase/phosphatase using 13C and 31P NMR. Biochem. J. 1999, 342, 567-580. [CrossRef] [PubMed]

89. Wong, J.M.W.; de Souza, R.; Kendall, C.W.C.; Emam, A.; Jenkins, D.J.A. Colonic health: Fermentation and short chain fatty acids. J. Clin. Gastroentrol. 2006, 40, 235-243. [CrossRef]

90. Herrera, E. Metabolic adaptations in pregnancy and their implications for the availability of substrates to the fetus. Eur. J. Clin. Nutr. 2000, 54, S47-S51. [CrossRef] [PubMed]

91. Baumann, M.U.; Deborde, S.; Illsley, N.P. Placental glucose transfer and fetal growth. Endocrine 2002, 19, 13-22. [CrossRef]

92. Ungar, P.S.; Sponheimer, M. The diets of early hominins. Science 2011, 334, 190-193. [CrossRef] [PubMed]

93. Aiello, L.C.; Wheeler, P. The expensive-tissue hypothesis: The brain and the digestive system in human and primate evolution. Curr. Anthropol. 1995, 36, 199-221. [CrossRef]

94. Lee, S.-H.; Wolpoff, M.H. The pattern of evolution in Pleistocene human brain size. Paleobiology 2009, 29, 186-196. [CrossRef]

95. Bramble, D.M.; Lieberman, D.E. Endurance running and the evolution of Homo. Nature 2004, 432, 345-352. [CrossRef] [PubMed]

96. Shahack-Gross, R.; Berna, F.; Karkanas, P.; Lemorini, C.; Gopher, A.; Barkai, R. Evidence for the repeated use of a central hearth at Middle Pleistocene (300 ky ago) Qesem Cave, Israel. J. Arch. Sci. 2014, 44, $12-21$. [CrossRef]

97. Roebroeks, W.; Villa, P. On the earliest evidence for habitual use of fire in Europe. Proc. Natl. Acad. Sci. USA 2011, 108, 5209-5214. [CrossRef] [PubMed]

98. Gowlett, J.A. The discovery of fire by humans: A long and convoluted process. Philos. Trans. R. Soc. B 2016, 371, 20150164. [CrossRef] [PubMed]

99. Wrangham, R.W.; Jones, J.H.; Laden, G.; Pilbeam, D.; Conklin-Brittain, N.L. The raw and the stolen: Cooking and the ecology of human origins. Curr. Anthropol. 1999, 40, 567-594. [CrossRef] [PubMed] 
100. Wrangham, R.W.; Carmody, R. Human adaptation to the control of fire. Evol. Anthropol. 2010, 19, $187-199$. [CrossRef]

101. Barton, H.; Matthews, P.J. Taphonomy. In Ancient Starch Research; Torrence, R., Barton, H., Eds.; Left Coast Press Inc.: Walnut Creek, CA, USA, 2006; pp. 5-94.

102. BeMiller, J.N. Carbohydrate Chemistry for Food Scientists, 2nd ed.; AACC International: St Paul, MN, USA, 2007; Chapter 6, pp. 173-225, ISBN 978-1-891127-3-3.

(c)

(C) 2018 by the authors. Licensee MDPI, Basel, Switzerland. This article is an open access article distributed under the terms and conditions of the Creative Commons Attribution (CC BY) license (http://creativecommons.org/licenses/by/4.0/). 